\title{
KOMUNIKASI GERAKAN SOSIAL MELALUI PENYADARAN PETANI DALAM KONFLIK AGRARIA
}

\author{
Social Movement Communication through the Awareness of Farmers in Agrarian Conflict
}

\author{
Ahmad Jazilil Mustopa ${ }^{1, *)}$, Dwi Sadono, Dwi Retno Hapsari
}

${ }^{1}$ Program Studi Komunikasi Pembangunan, Fakultas Ekologi Manusia, IPB University, Bogor 16680, Indonesia

${ }^{*}$ E-mail: jazilil_ahmad@apps.ipb.ac.id

\begin{abstract}
Indonesia has a long history of agrarian conflicts that include peasants in it. One of them is as happened in Caringin Sukabumi where peasants are dealing with companies in agrarian conflict. The farmers assume the injustices in which the land they cultivate has a land rights title on behalf of the company. This condition raised a resistance of social movements in the peasant community that largely influenced by the role of organic intellectual consisting of a non - government organization and students assisted by local peasants. One of the influence is the awareness of farmers. This research aims to analyse the strategies of actors in the process of farmer awareness that are divided into magical awareness, naïve awareness, and critical awareness through dialogical communication. This research uses a qualitative method by the case an agrarian conflict between the peasant as a land cultivator and PT. Surya Nusa Nadicipta (SNN) as building right title holder in Caringin. The results of the study shows that dialogic communication strategies change the peasants awareness to be more critical, even though naive awareness is still inherent. So, it creates a new awareness type named critical naive awareness.
\end{abstract}

Keywords: awareness, dialogical communication, social movement

\begin{abstract}
ABSTRAK
Indonesia mempunyai sejarah panjang terkait konflik agraria yang menyertakan petani di dalamnya. Salah satunya seperti yang terjadi di Caringin, Sukabumi dimana petani berhadapan dengan perusahaan dalam konflik agraria. Petani menganggap ada dominasi ketidakadilan karena tanah yang mereka garap ternyata surat hak gunanya adalah atas nama perusahaan. Kondisi ini memunculkan gerakan sosial perlawanan dari petani yang dalam prosesnya banyak dipengaruhi oleh peran intelektual organik yang terdiri dari Organisasi non Pemerintah serta mahasiswa yang dibantu oleh tokoh tani lokal. Pengaruh tersebut salah satunya berupa penyadaran kepada petani. Penelitian ini bertujuan menganalisis strategi para aktor dalam proses penyadaran petani yang terbagi dalam kesadaran magis, naif dan kritis melalui komunikasi dialogis. Penelitian ini menggunakan metode kualitatif dengan studi kasus konflik agraria yang terjadi di Caringin Sukabumi antara petani sebagai penggarap lahan dan PT. SNN sebagai pemegang hak guna bangunan (HGB) atas lahan tersebut. Hasil penelitian menunjukkan strategi komunikasi dialogis membawa perubahan kesadaran petani menjadi lebih kritis walaupun kesadaran naif masih melekat sehingga memunculkan jenis kesadaran baru berupa kesadaran naif kritis.
\end{abstract}

Kata kunci: penyadaran, komunikasi dialogis, gerakan sosial

Content from this work may be used under the terms of the Creative Commons Attribution-ShareAlike 4.0 International License.. Any further distributionof this work must maintain attribution to the author(s) and the title of the work, journal citation and DOI.

Published under Department of Communication and Community Development Science, IPB University ISSN: 1693-3699| EISSN: 2442-4102 


\section{PENDAHULUAN}

Masalah agraria menurut Tauchid (2009) adalah soal hidup dan penghidupan manusia, karena tanah adalah asal dan sumber makanan bagi manusia. Perebutan tanah berarti perebutan makanan, untuk itu orang rela menumpahkan darahnya demi mempertahankannya. Konflik agraria yang melibatkan petani menurut Rachman (2017) tercatat dimulai sejak zaman kolonialisme di saat meluasnya usaha perkebunan dan tekanan pajak yang besar serta pencaplokan tanah petani. Perlawanan yang dilakukan petani bervariasi, dari yang bersifat demonstrasi, pemberontakan, tindakan-tindakan individu hingga aksi kolektif. Skala konflik lokal hingga skala regional dan dari yang tergolong spontan hingga yang tergolong terorganisir.

Di Indonesia, ketimpangan dalam distribusi kepemilikan tanah adalah pemicu utama konflik pertanahan dan dalam konflik perebutan tanah, kerap kali muncul perlawanan. Di Jawa, masyarakat petani yang terlibat dalam konflik perebutan hak atas tanah kebanyakan merupakan peasant society (masyarakat petani) yang belum banyak bergeser dari stratifikasi sosial terendah (Amin, 2010) Perlawanan petani dalam konflik agraria salah satunya terjadi di Kecamatan Caringin Sukabumi, di mana sedang terjadi konflik agraria antara petani dan perusahaan PT. SNN yang memiliki hak guna bangunan (HGB) atas lahan yang selama ini digarap oleh petani sehingga memunculkan gerakan sosial petani dalam rangka mempertahankan lahan garapannya. Gerakan sosial dalam bentuk aksi kolektif secara aktif dilakukan oleh para petani dengan dipelopori oleh tokoh-tokoh gerakan dari luar yang menurut Gramsci (1971) disebut sebagai intelektual organik. Aktor ini disebut sebagai aktivis agraria perkotaan dari kalangan akademisi dan LSM dalam rangka membantu pemimpin tani desa dan membawa pola gerakan dengan menyampaikan tuntutan lewat demonstrasi, kampanye media, lobi dan advokasi kebijakan.

Gerakan sosial dalam bentuk aksi kolektif perlawanan petani tentunya didasari oleh kesadaran dari para pelaku yang terlibat. Menurut Ife dan Tesoriero (2008) tindakan kolektif dibutuhkan dalam menghadapi permasalahan yang tidak bisa dipecahkan individu. Dapat menjadi tindakan yang jauh lebih kuat dan efektif daripada tindakan individual dan berkontribusi terhadap proses peningkatan kesadaran (Asia et al., 2018). Kesadaran kritis (critical consciousness) adalah kesadaran yang diharapkan para aktor dapat dimiliki oleh seluruh petani yang terdampak konflik. Menurut Freire (2008), kesadaran bukanlah teknik atau transfer informasi atau bahkan untuk pelatihan keterampilan, tetapi merupakan proses dialogis yang mengantarkan individu bersama-sama untuk menyelesaikan masalah-masalah eksistensial mereka. Dialog-lah yang menuntut adanya pemikiran kritis, yang mampu melahirkan pemikiran kritis. Tanpa dialog tidak aka nada komunikasi, dan tanpa komunikasi tidak akan mungkin ada pendidikan sejati. Membangun kesadaran petani melalui komunikasi dialogis adalah langkah yang tidak mudah, karena kondisi dalam konflik agraria menciptakan pola bagi kaum yang tertindas yaitu petani yang terus merasa dalam ketakutan dalam merebut kebebasannya.

Membangun aksi kolektif gerakan sosial, perlu adanya kesadaran pada semua peran yang terlibat di dalam gerakan. Kesadaran dalam gerakan sosial sebenarnya sudah mulai dibahas dalam konsepsi sosiologis oleh Durkheim (1951) yang dipahami dalam dua bentuk, yaitu masyarakat mekanik dan organik. Masyarakat mekanik mempunyai conscience collective (kesadaran umum) yang mendasari tindakan yang bersifat kolektif. Kesadaran umum dapat juga sebagai moral bersama yang koersif pada setiap anggotanya. Kesadaran organik bersifat lebih kompleks di mana individu terhubung satu sama lain atas dasar fungsi kebutuhan. Kesadaran organis ini menjadi dasar dari berkembangnya masyarakat modern. Durkheim menjelaskan 2 jenis solidaritas sosial, yaitu solidaritas mekanik dan solidaritas organic (Susan, 2014).

Teori tentang penyadaran tidak akan terlepas dari Paulo Freire dengan konsep pendidikan yang membebaskannya, kesadaran adalah hasil dari pendidikan yang membebaskan. Freire (2008) membagi kesadaran manusia menjadi kesadaran magis, naif, dan kritis. Kesadaran magis (magical consciousness) adalah kesadaran masyarakat yang tidak mampu melihat kaitan antara satu faktor dengan faktor lainnya. Kesadaran magis lebih melihat faktor di luar manusia (natural maupun supranatural) sebagai penyebab dari ketidakberdayaannya. Kedua, kesadaran naif (naival consciousness) yang lebih melihat aspek manusia menjadi akar permasalahan dalam masyarakat. Dalam kesadaran ini masalah etika, kreativitas, need for achevment dianggap sebagai penentu perubahan sosial. Oleh karena itu, man power development adalah sesuatu yang diharapkan sebagai pemicu perubahan. Kesadaran ketiga dan terpenting adalah kesadaran kritis (critical consciousness) yang melihat aspek sistem dan struktur sebagai sumber masalah. 
Proses konsientisasi, yaitu pembangkitan kesadaran kritis atau critical consciousness raising (conscientização dalam Bahasa Portugis, bahasa asli Freire) yang digagas Paulo Freire, menurut Goldbard (2006) merupakan proses pembangkitan kesadaran yang berakar dari ilmu pedagogi atau pendidikan dan pengajaran, khususnya pendidikan orang dewasa. Aspek yang mendasari konsientisasi Freire ini mirip dengan prinsip consciousness raising para feminis yang berasals dari ketertindasan dan mengedepankan aksi kolektif dan dialog dalam mencapai perubahan sosial. Akan tetapi, konsientisasi Freire ini berbeda dengan consciousness raising pada gerakan perempuan karena pada consciousness raising gerakan perempuan dapat melibatkan transmisi pengetahuan yang telah dipilah sebelumnya (preselected knowledge), yaitu peningkatan kesadaran terjadi pada pengungkapan pengetahuan tersebut (Moenawar et al., 2019).

Freire (2008) menyatakan bahwa kesadaran bukanlah teknik atau transfer informasi atau bahkan untuk pelatihan keterampilan, tetapi merupakan proses dialogis yang mengantarkan individu bersama-sama untuk menyelesaikan masalah-masalah eksistensial mereka. Dialog-lah yang menuntut adanya pemikiran kritis, yang mampu melahirkan pemikiran kritis. Tanpa dialog tidak akan ada komunikasi, dan tanpa komunikasi tidak akan mungkin ada pendidikan sejati.

Penting untuk sebuah gerakan sosial berjalan berkesinambungan, di mana semua peran harus memiliki pemahaman yang sama dan sadar bahwa masalah yang terjadi akibat sistem dan struktur yang bermasalah. Syawaludin (2014) menyebutkan bahwa munculnya kesadaran yang meneruskan aksi-aksi perlawanan dan membangun kekuatan perlawanan dengan identitas gerakan perlawanan petani adalah bentuk menjaga dan memelihara nafas perlawanan terhadap pihak yang lebih kuat. Strategi komunikasi yang dilakukan dalam membangun kesadaran adalah melalui komunikasi dua arah atau dialogis yang membawa persamaan dan keadilan antar komunikan.

Pendekatan komunikasi dialogis dalam proses penyadaran mengacu pada komunikasi dua arah seperti teori rasionalitas komunikatif dari Habermas. Teori ini menurut Ansori (2009) menekankan pada komunikasi intersubjektif (subjek-subjek) yang menghendaki komunikasi yang dilakukan antara dua subjek sama kedudukannya, dialogis, dan didasarkan atas argumen yang rasional, saling pengertian. Konsensus atau kesepakatan yang dihasilkan adalah lahir dari pemahaman intersubjektif peserta diskusi. Komunikasi intersubjektif sebagai bentuk praksis emansipatoris dapat terjadi ketika setiap individu meneguhkan empat klaim validitas; kebenaran, kejujuran, kejelasan, dan ketepatan. Komunikasi harus jauh dari tekanan atau dominasi. Di samping itu, komunikasi intersubjektif akan terbangun ketika individu berada dalam posisi yang sederajat serta menetralkan kepentingankepentingannya. Komunikasi dialogis juga dikemukakan oleh Tufte \& Mefalopulos (2009) di mana proses dan hasilnya terbuka dan ruang lingkup pembahasan masalahnya akan menghasilkan pengetahuan dan solusi baru, bukan hanya sebatas mentransmisikan informasi. Berbeda halnya dengan komunikasi satu arah (monolog) seperti diseminasi informasi, kampanye media dan difusi lainnya.

Dialog mempunyai beberapa fungsi seperti yang diungkapkan Baxter, pertama sebagai pembentuk hubungan (relationship are made in dialogue), dialog menentukan bagaimana anda memberi makna atau mendefinisikan hubungan dengan orang lain. Kedua, dialog memberikan peluang untuk mencapai kesatuan dalam perbedaan (dialogue affords an opportunity to achieve a unity within diversity), dengan adanya dialog kita dapat mengelola kekuatan yang mendorong terjadinya pemisahan dan kekuatan yang mendorong terjadinya penyatuan. Ketiga, dialog bersifat estetis (dialogue is aesthetic) yang mencakup rasa keseimbangan, kesatuan, bentuk dan keseluruhan, dengan demikian walaupun kehidupan sosial tampaknya "berantakan" tetapi kita dapat memberikan rasa keteraturan, perasaan keseluruhan, hubungan yang menyatu dan memiliki perasaan bersama. Keempat, dialog adalah wacana (discourse) dan hubungan bukanlah sesuatu yang dikerjakan secara kognitif dalam otak seseorang, tetapi merupakan produk percakapan (Morissan, 2015).

Gerakan sosial yang terjadi di Desa Pasirdatar Indah dan Sukamulya Kecamatan Caringin, Sukabumi dimulai dari konflik terbuka antara petani dan PT. SNN pada tahun 2015. Perlawanan ini tidak terlepas dari peran aktor yang memberikan pemahaman kepada para petani terkait hak-hak agrarianya. Gerakan sosial dalam bentuk aksi kolektif perlawanan petani tentunya didasari oleh kesadaran kritis dari para pelaku yang terlibat. Kesadaran kritis (critical consciousness) menurut Freire banyak melihat aspek sistem dan struktur sebagai sumber masalah. Pendekatan struktural menghindari blaming the victims dan lebih menganalisis secara kritis struktur dan sistem sosial, politik, ekonomi, budaya dan implikasi pada masyarakat. Kesadaran kritis merupakan proses dialogis yang mengantarkan individu bersama-sama untuk menyelesaikan masalah-masalah eksistensial mereka. 
Kesadaran kritis ini lah yang membawa petani dan para pelaku gerakan sosial secara kolektif bergerak menyelesaikan masalahnya, bukan hanya terkait masalah ekonomi karena ketimpangan agraria semata, namun juga pada aspek sosial lainnya. Kesadaran kritis tidak hanya selesai dalam tahap pemikiran penyelesaian masalah, namun juga masuk ke dalam penyelesaian praksis di mana petani turut serta bergerak sebagai langkah konkret penyelesaian masalah (Yunus, 2007).

Membangun kesadaran petani adalah langkah yang tidak mudah, karena seperti yang dikatakan Freire (2008) kondisi dalam konflik agraria menciptakan pola bagi kaum yang tertindas yaitu petani yang terus merasa dalam ketakutan dalam merebut kebebasannya, sehingga dalam gerakan sosial ini apakah kesadaran kritis dari para petani menjadi salah satu faktor dalam terbentuknya gerakan sosial aksi kolektif petani. Proses penyadaran kritis dari para aktor terhadap petani melalui proses dialogis menjadi penting untuk ditelaah. Proses penyadaran yang dilakukan apakah mengantarkan petani untuk turut serta dan berpartisipasi secara bersama-sama untuk menyelesaikan masalah-masalah eksistensialnya melalui aksi kolektif gerakan sosial. Hal inilah yang menjadi tujuan penelitian bagaimana strategi komunikasi penyadaran yang dilakukan oleh para aktor berlangsung dan berhasil jika dilihat dari terciptanya gerakan sosial perlawanan yang dilakukan petani.

Penelitian tentang gerakan sosial banyak dibahas dalam kajian sosiologi yang ingin melihat aspek perubahan sosial dan struktur sosial masyarakat serta dampak dari gerakan. Seperti yang diungkapkan oleh Roggeband \& Klandermans (2017) terkait jumlah publikasi dengan tema gerakan sosial dalam berbagai disiplin ilmu antara tahun 1975-2015. Roggerband dan Klandermans mengumpulkan data hasil penelitian terkait gerakan sosial menggunakan Google Scholar dengan kata kunci pencarian social movement dan disiplin ilmu sosial yang dituju. Hasilnya, penelitian terkait gerakan sosial banyak dikaji oleh bidang sosiologi sebanyak 175.710 publikasi, disusul bidang ilmu politik sebanyak 56.010 publikasi, selanjutnya bidang antropologi sebanyak 45.540 publikasi, kemudian secara berurutan bidang sejarah 45.261 publikasi, bidang psikologi sosial sejumlah 25.900 publikasi, bidang hukum sejumlah 7.698 publikasi, bidang studi organisasi sejumlah 6.052 publikasi dan bidang ilmu komunikasi sejumlah 1.026 publikasi.

Di Indonesia, gerakan sosial juga sudah pernah diteliti namun bukan dalam kasus konflik agraria, seperti hasil penelitian Setyadi (2016) yang menemukan bahwa munculnya gerakan sosial dipengaruhi oleh kurangnya komunikasi antara pemerintah dan masyarakat dalam penanggulangan resiko. Penelitian komunikasi gerakan sosial juga diteliti oleh Hapsari (2016) yang meneliti bagaimana jaringan komunikasi berperan mendorong masyarakat berpartisipasi dalam gerakan sosial pelestarian lingkungan.

Penelitian-penelitian terdahulu terkait gerakan sosial tersebut masih belum banyak yang menggunakan kerangka ilmu komunikasi sebagai aspek utama yang diteliti. Penelitian yang menggunakan aspek komunikasi dalam gerakan sosial pun belum ada yang menyentuh pada ranah konflik agraria. Hal inilah yang membuat pentingnya penelitian ini yang memfokuskan pada gerakan sosial dalam konflik agraria dengan menggunakan kerangka ilmu komunikasi. Penelitian ini akan membahas bagaimana komunikasi berperan dalam membangun gerakan sosial di antara petani dalam konflik agraria melalui aktor-aktor gerakan.

Sejak konflik terbuka antara petani dan PT. SNN dalam konflik agraria di Kecamatan Caringin Sukabumi pada tahun 2015, perjuangan petani tidak lagi dilakukan secara pasif. Awalnya petani hanya melawan dan melakukan protes dengan tidak bersedia mengosongkan lahan atas intimidasi pihak perusahaan. Perlahan, aksi protes petani lebih terbuka dengan dilakukannya aksi demonstrasi, melawan penggusuran lahan bahkan dengan tindak kekerasan. Perubahan gerakan protes petani ini diakibatkan oleh masuknya para aktor intelektual gerakan yang terdiri dari mahasiswa, tokoh masyarakat dan lembaga swadaya masyarakat yang berhasil mempersuasi petani untuk melakukan aksi gerakan sosial yang lebih masif.

Gerakan sosial ini tidak terlepas dari kerangka aksi kolektif dan faktor pendukungnya, seperti dimunculkannya kesadaran kritis di antara petani. Kesadaran kritis yang tumbuh di antara petani terbentuk melalui proses komunikasi dialogis melalui aktor-aktor gerakan. Komunikasi dialogis menciptakan kesadaran petani yang tadinya masuk dalam kategori kesadaran magis dan naif menjadi kesadaran kritis. Kesadaran kritis petani dicirikan dengan mulai mandirinya petani dalam gerakan serta mampu membuat solusi atas permasalahan yang mereka alami tanpa bergantung lagi dengan para aktor. Petani mampu menganalisis secara kritis struktur dan sistem sosial, politik, ekonomi, budaya 
dan implikasi pada masyarakat. Kesadaran kritis merupakan proses dialogis yang mengantarkan individu bersama-sama untuk menyelesaikan masalah-masalah eksistensial mereka. Kesadaran kritis ini lah yang membawa petani dan para pelaku gerakan sosial secara kolektif bergerak menyelesaikan masalahnya, bukan hanya terkait masalah ekonomi karena ketimpangan agraria semata, namun juga pada aspek sosial lainnya.

Perubahan yang signifikan terhadap gerakan sosial yang terjadi dalam konflik agraria ini dapat ditarik hipotesis pengarah yaitu, terdapat proses penyadaran kritis dari para aktor terhadap petani melalui proses dialogis yang mengantarkan petani untuk turut serta dan berpartisipasi secara bersamasama untuk menyelesaikan masalah-masalah eksistensialnya melalui aksi kolektif gerakan sosial.

\section{METODE}

Penelitian ini menggunakan pendekatan kualitatif dengan paradigma kritis. Pendekatan kualitatif adalah suatu proses penelitian dan pemahaman yang berdasarkan fenomena sosial dan masalah manusia. Pada pendekatan ini, peneliti membuat suatu gambaran kompleks, meneliti katakata, laporan terinci dari pandangan responden, dan melakukan studi pada situasi yang alami (Creswell, 2009). Paradigma kritis memandang bahwa realitas kehidupan sosial bukanlah merupakan suatu hal yang netral. Realitas kehidupan sosial dipengaruhi oleh berbagai kekuatan seperti politik, ekonomi, dan sosial. Konsentrasi analisis pada paradigma kritis adalah menemukan kekuatan yang dominan tersebut dalam memarjinalkan dan meminggirkan kelompok-kelompok lain yang tidak dominan (Eriyanto, 2011).

Komunikasi kritis dalam ilmu komunikasi dijelaskan pada tradisi kritis dengan mengemukakan tiga hal penting (Littlejohn \& Foss, 2011). Pertama, tradisi kritik mencoba memahami sistem yang sudah dianggap benar, struktur kekuatan dan keyakinan atau ideologi yang mendominasi masyarakat dengan pandangan tertentu di mana minat-minat disajikan oleh struktur-struktur kekuatan tersebut. Kedua, para ahli teori kritik pada umumnya tertarik dengan membuka kondisi-kondisi sosial yang menindas dan rangkaian kekuatan untuk mempromosikan emansipasi atau masyarakat yang lebih bebas dan lebih berkecukupan. Memahami penindasan dalam menghapus ilusi-ilusi ideologi dan bertindak mengatasi kekuatan-kekuatan yang menindas. Ketiga, menciptakan kesadaran untuk menggabungkan teori dan tindakan.

Penelitian ini menggunakan desain penelitian studi kasus instrinsik yaitu studi kasus yang menekankan pada pemahaman yang mendalam terhadap kasus tunggal yang disebabkan kasus tersebut menarik. Tujuan desain ini tidak dimaksudkan untuk memahami konstruk abstrak atau fenomena umum yang diharapkan dapat dilakukan generalisasi, melainkan lebih ditekankan pada kepentingan instrinsik, dan menghilangkan generalisasi, serta tidak dimaksudkan untuk membentuk teori baru (Idrus, 2009). Desain penelitiam ini dipilih karena hanya fokus pada gerakan sosial berlatar konflik agraria dan hanya pada satu lokasi dan kejadian tertentu. Penelitian ini tidak ditujukan untuk menciptakan ataupun mengoreksi sebuah teori, namun menjelaskan gerakan sosial konflik agraria dengan menggunakan teori.

Penelitian dilaksanakan di Desa Pasir Datar Indah dan Desa Sukamulya, Kecamatan Caringin, Sukabumi Jawa Barat sebagai lokasi konflik agraria berlangsung dan dilaksanakan dari Bulan Mei hingga Bulan Oktober 2018. Metode pengumpulan data sendiri sesuai pernyataan Yin (2015) terdiri dari enam sumber bukti yang dapat dijadikan fokus bagi pengumpulan data studi kasus. Enam sumber bukti tersebut selain dokumen dan wawancara adalah rekaman arsip, observasi partisipan, dan perangkat fisik. Partisipasi yang dilakukan adalah dengan tipe partisipan sebagai pengamat seperti yang dijelaskan oleh Creswell (2015) yang membagi tipe partisipasi dalam empat tipe. Pertama, partisipan sempurna di mana peneliti terlibat secara penuh dengan masyarakat yang sedang diamatinya. Kedua, partisipan sebagai pengamat, yaitu peneliti berpartisipasi dalam aktivitas di tempat penelitian. Guna mendapatkan pandangan insider dan data subjektif. Ketiga, non partisipan yaitu peneliti merupakan outsider dari kelompok yang diteliti menyaksikan dan membuat catatan dari kejauhan. Keempat, pengamat sempurna, yaitu peneliti tidak terlihat atau diketahui oleh masyarakat yang diteliti.

Penentuan informan dan subjek penelitian dilakukan dengan metode purposive sampling yaitu teknik pengambilan sampel sumber data dengan pertimbangan tertentu yang memungkinkan 
mempermudah peneliti menjelajahi objek/situasi sosial yang diteliti, dilanjutkan dengan metode snow ball (Sugiyono, 2014). Dalam penelitian kualitatif menurut Creswell (2015) para peneliti dapat melakukan sampling pada level tempat, pada level peristiwa atau proses dan pada level partisipan.

Informan terdiri dari aktor gerakan sosial meliputi mahasiswa berjumlah dua orang, LSM dua orang dan tokoh tani lokal dua orang. Subjek penelitian sendiri adalah petani terdampak konflik berjumlah sembilan orang. Penelitian dimulai dengan mewawancarai aktor gerakan untuk mengetahui sejauh mana keberhasilan strategi yang mereka gunakan dalam proses penyadaran. Petani yang menjadi subjek penelitian adalah petani yang aktif terlibat dalam gerakan yang dianggap sudah melalui proses penyadaran. Jumlah subjek penelitian dibatasi saat sudah mencapai titik jenuh data, di mana informasi yang didapatkan dianggap sama dan mewakili.

Pengumpulan data yang dilakukan dalam penelitian ini berupa wawancara mendalam dengan petani. Beberapa sumber data seperti jumlah partisipan petani yang terlibat dalam gerakan sosial pada fase awal dan saat dilakukan penelitian juga didapatkan melalui wawancara dengan petani dan aktor gerakan yang terlibat. Metode pengumpulan data lainnya melalui observasi dengan mendatangi lokasi konflik dan mengamati beberapa kejadian secara langsung serta beberapa kali mengikuti agenda penyelesaian konflik, metode dokumenter dengan menelaah beberapa dokumen terkait konflik. Metode bahan visual diperoleh melalui beberapa arsip yang disimpan beberapa tokoh petanil. FGD dilakukan dengan kelompok mahasiswa yang masih aktif dalam mendampingi petani.

Analisis data studi kasus kualitatif menurut Stake adalah dengan membuat langkah metodik sederhana dalam kajian. Menurutnya, yang perlu dilakukan adalah konsentrasikan perhatian pada seluruh kasus yang terjadi, dengan catatan bahwa aktivitas logika tersebut tidak sekedar bersifat observatorial, namun pada prinsipnya lebih bersifat reflektif. Seorang peneliti pada prinsip reflektif berarti fokus untuk secara cermat mengkaji berbagai kesan-kesan, melibatkan diri dalam upaya menghimpun ulang dan merekam (Denzin \& Lincoln, 2009).

\section{HASIL DAN PEMBAHASAN}

Secara umum, tradisi teoritis dalam studi gerakan sosial terbagi menjadi tiga bagian, yaitu klasik, neo klasik dan gerakan sosial baru. Tradisi klasik meliputi sebagian besar studi-studi dalam perilaku kolektif seperti crowd, riot dan rebel, utamanya oleh para psikolog Barat dan para sejarawan dari sebelum tahun 1950 an. Tradisi neo klasik dihubungkan dengan tradisi utama dalam studi gerakan sosial lama. Gerakan petani dapat dikategorikan ke dalam gerakan sosial lama (old social movement) maupun baru (new social movement). Termasuk dalam klasifikasi 'lama' jika gerakannya berorientasi pada persoalan-persoalan ekonomi, dan kebutuhan materi lain. Namun jika gerakan tersebut berhubungan dengan nilai-nilai dan isu-isu modern seperti: HAM, keadilan, persamaan hak, lingkungan hidup, perdamaian, dll, maka disebut dengan gerakan sosial baru (Singh, 2010). Gerakan sosial yang terjadi di Caringin Sukabumi yang pada awalnya lebih kepada masalah lahan yang akan berimplikasi terhadap pendapatan petani yang tergolong dalam kelompok peasant mulai masuk pada gerakan sosial baru dengan tujuan yang lebih luas seperti reforma agraria.

Sejarah konflik agraria yang terjadi terbagi ke dalam beberapa periode, periode pertama pasca tahun 1945 di mana lahan seluas kurang lebih 400 Ha bekas perkebunan teh Belanda digarap masyarakat. Periode kedua Tahun 1973 saat PT. Gedeh Wangi (GW) datang dan menanam pohon nilam di wilayah seluas 30 persen dari total 320 hektar tersebut dari tahun 1973-1978 dan tahun 1985, terbit izin Hak Guna Usaha (HGU) nya. Periode ketiga, tahun 1993-1994 saat datangnya PT. Surya Nusa Nadicipta (SNN) yang mengambil alih lahan yang sebelumnya dikuasai PT. GW dan masyarakat. Tahun 1995, PT. GW melepaskan HGU ke negara untuk kepentingan HGB PT. SNN untuk agrowisata, resort dan lapangan golf. PT. SNN mendapatkan lahan SHM masyarakat sekitar seluas 45 hektar dan tanggal 21 Juni 1996 terbit izin HGB nya. Periode keempat, tahun 2015 PT. SNN memerintahkan petani mengosongkan lahannya sehingga pada September 2015, mahasiswa dan Serikat Petani Indonesia datang dalam memberikan Advokasi. Tanggal 12 April 2017 PT. SNN Melaporkan 5 orang petani ke Kepolisian atas tuduhan penggunaan lahan atas izin pemilik. Saat ini gerakan sosial terus berlangsung dengan metode advokasi non-ligitasi.

Aktor-aktor gerakan yang terlibat dalam proses gerakan sosial petani Caringin Sukabumi terdiri dari mahasiswa, lembaga swadaya masyarakat dalam hal ini Serikat Petani Indonesia (SPI) dan tokoh 
tani lokal. Kehadiran mahasiswa dan SPI dibantu tokoh tani lokal dalam arena konflik adalah untuk memberikan penyadaran dalam membangun gerakan sosial perlawanan. Petani yang sebelumnya mendirikan paguyuban GP3S sebagai wadah solidaritas dan alat perjuangan, hanya sebatas bertahan dan tidak mengindahkan perintah pengosongan lahan serta mencoba bernegosiasi dengan perusahaan, sehingga tidak ada hasil yang maksimal. Kehadiran aktor gerakan membawa warna baru dalam gerakan sosial petani dengan memberikan penyadaran yang bertujuan menghadirkan partisipasi petani dalam rangka gerakan sosial perlawanan.

Strategi komunikasi yang dilakukan oleh para aktor dalam kontribusinya terhadap gerakan sosial konflik agraria ini berbeda-beda. Mahasiswa sebagai intelektual organik pertama yang mendatangi petani yang berkonflik berkontribusi pada tahap awal dimulainya gerakan. Mahasiswa ini yang memulai penyadaran awal terhadap petani dengan melakukan dialog secara intens serta mendatangi secara langsung tokoh-tokoh petani. Kontribusi SPI sendiri lebih signifikan perannya dibanding aktor gerakan yang lain selama proses gerakan sampai saat ini. SPI diperkenalkan kepada petani oleh mahasiswa untuk memberikan penyadaran dengan lebih terorganisir melalui materi-materi dialog yang lebih berbobot. Kontribusi tokoh tani lokal sendiri dalam gerakan adalah ketika mereka berinisiatif membuat organisasi dalam menolak mengosongkan lahan sebagai bentuk perlawanan. Tokoh tani lokal berperan dalam proses strategi komunikasi yang dilakukan oleh intelektual organik dengan menjadi media penghubung dengan petani lainnya dan menjadi orang yang pertama kali hadir dalam setiap aktivitas gerakan.

\section{Kesadaran Kritis}

Freire (2008) menjelaskan bahwa pemimpin revolusi bukan datang kepada rakyat untuk menyampaikan kepada mereka berita keselamatan, tetapi dalam rangka mengetahui lewat dialog dengan mereka tentang situasi obyektif serta kesadaran kaum tertindas tentang situasi itu berbagai taraf pemahaman mereka terhadap diri sendiri, dan dunia di mana dan dengan mana mereka mengada. Kaum tertindas menurut Freire adalah kaum yang bisa membebaskan dirinya dan kelompoknya sendiri dengan terlebih dahulu paham dan sadar. Kesadaran menurut Freire sendiri terbagi ke dalam kesadaran magis, kesadaran naif dan kesadaran kritis.

Kesadaran awal masyarakat sebagian besar berada pada kesadaran magis dan naif dan sebagian kecil masuk pada tahap kesadaran kritis. pembagian kesadaran petani Caringin adalah sebagai berikut:

1) Kesadaran Magis

Pada hakikatnya kesadaran magis adalah kesadaran yang tidak bisa membuat keterkaitan antara sebab dan akibat sehingga sebab atau akibat dalam kesadarannya adalah takdir semata. Hal ini lah yang membuat para aktor dalam komunikasi dengan mereka tidak boleh bersikap menggurui, karena bisa saja kesadaran magis mereka berasal dari pengetahuan secara natural ataupun keyakinan yang mereka peroleh dari ajaran agama dan keyakinannya. Kesadaran magis ini seperti petani yang pada awalnya tidak mau terlibat sama sekali karena sudah pasrah akan keadaan, mereka menganggap lahan yang mereka garap akan menunggu waktu saja untuk diambil pihak perusahaan. Bentuk ajakan aktor pun sebatas memberikan pilihan dan menerapkan pesan akan sebab dan akibat jika mengambil pilihan bagi petani dengan kesadaran magis ini, seperti ungkapan salah satu aktor dari mahasiswa:

"kita hanya menyampaikan waktu itu, ini loh konsekuensinya, kalau gak mau berjuang ya silahkan tanahnya diambil. Kalau berjuang kan masih ada kemungkinan bisa tetap bertani di lahan tersebut" (HYI, Mahasiswa)

\section{2) Kesadaran Naif}

Kesadaran naif terlihat ketika salah satu tokoh tani lokal yang baru mengalami masa tahanan dan masih trauma mengikuti keinginan perusahaan dengan menyerahkan lahannya melalui pihak kecamatan karena dijanjikan lahan sekitar 100 Ha untuk petani garap dan dengan klausul tidak ada lagi pelaporan. Pendekatan komunikasi pada kelompok petani dengan kesadaran naif adalah dengan memotivasinya dan memberikan pengetahuan bagaimana posisi mereka dalam konflik. Petani dengan kesadaran ini harus diberikan gambaran terkait kekuatan mereka di mata hukum dalam konflik yang mereka alami. Salah satu bentuk kesadaran naif ini seperti ungkapan salah satu petani sebagai berikut: 
"Sebetulnya masih pada kuat dengan komitmen masing-masing, tapi kalau dilihat pada titik win-win itu sudah hampir. Sampai saat ini memang belum (sepakat semuanya), jadi keinginan perusahaan yang 110 itu hanya sebatas pinjam pakai dan untuk pengelolaan dikasih oleh perusahaan dengan sistemnya kerja sama. Tapi masyarakat bersikeras ingin mandiri. Tapi, jika kita tidak dapat semuanya, paling tidak ada yang kita dapat, 20\%, 30\%. Dari $320 \mathrm{Ha}$ yang dipertahankan oleh masyarakat, sekarang berkurang di sekitar $100 \mathrm{Ha}$ ". (ASP-Tokoh tani lokal)

\section{3) Kesadaran Kritis}

Kesadaran kritis petani dicirikan dengan pahamnya mereka akan akar dari masalah dan cara penyelesaiannya. Mereka menjadi subjek dari perubahan itu sendiri. Perlawanan-perlawanan yang dilakukan petani sebagai bentuk aktualisasi adalah salah satu wujud kesadaran kritis tersebut. Pendekatan komunikasi pada kelompok petani dengan kesadaran kritis ini terbilang cukup mudah. Hal yang perlu dilakukan dengan kelompok kesadaran ini adalah intensitas komunikasi yang harus terjaga dalam rangka menjaga semangat dan menambahkan pengetahuan bagaimana aktualisasi diri dalam gerakan sosial. Petani dengan kesadaran kritis ini dicontohkan pada ungkapan petani berikut:

"Engga (takut) lah. Ya pasti itu, tergantung jiwa, kalau ini (saya) alhamdulillah, kalau istilahnya kalau sakit itu jadi nambah keberanian, dasar (pemahaman) sudah punya, pengalaman sudah dapat. Alhamdulillah, sudah tidak takutsoalnya”. (IWN-Petani)

Kesadaran petani selanjutnya bisa dikategorikan sebagai kesadaran naif-kritis, yaitu petanipetani yang menginisiasi paguyuban Gabungan Petani Penggarap Desa Pasir Datar dan Desa Sukamulya (GP3S). Berdirinya paguyuban ini menandakan mulainya kesadaran kritis yang muncul dengan harapan adanya perubahan sosial yang terjadi dengan melakukan perlawanan bersama, mengidentifikasi masalah dan solusi, namun paguyuban ini juga tidak terlepas dari motif-motif pribadi serta salah satu tujuan gerakan adalah mencoba bernegosiasi untuk memunculkan win-win solution yang bisa diterima kedua belah pihak yang berkonflik. Kesadaran seperti ini dikategorikan sebagai kesadaran naif, sehingga kelompok ini masuk dalam tipe kesadaran naif-kritis.

Konsep kesadaran naif-kritis ini juga pernah dibahas dalam penelitian Wijanarko (2014) yang meneliti bagaimana komunikasi gerakan sosial dipengaruhi oleh faktor kesadaran. Kesadaran naifkritis menjadi salah satu temuan dalam penelitiannya terkait bagaimana petani melakukan gerakan dalam rangka mendapatkan keadilan dalam penguasaan lahan melalui usulan peraturan desa (Perdes). Petani memahami tujuan Perdes adalah sebagai langkah awal kemandirian dan kedaulatan desa mereka, hal ini diidentifikasi sebagai kesadaran kritis, namun sisi lain petani masih berusaha menyesuaikan kehidupan mereka dengan keadaan yang ada yang diidentifikasi masuk dalam kesadaran naif.

\section{Dialog dan Proses Membangun Kesadaran Kritis}

Membangun kesadaran di antara petani adalah hal yang tidak mudah, mahasiswa yang datang adalah masyarakat asing yang harus menghadirkan kepercayaan terlebih dahulu. Proses menghadirkan kepercayaan di masyarakat petani adalah dengan berbaur dan berkomunikasi di setiap kesempatan. Para mahasiswa juga menginap secara bergantian di Desa terdampak konflik untuk menganalisa kondisi masyarakat. Selanjutnya, dalam rangka memberikan pemahaman serta kesadaran yang dilakukan oleh para mahasiswa adalah dengan mengidentifikasi tokoh-tokoh yang bisa memengaruhi khalayak, tokoh yang dihormati dan dituruti perkataannya oleh para petani untuk selanjutnya dijadikan target awal dalam membangun kesadaran. Tokoh-tokoh tersebut akan didatangi langsung ke kediamannya dan diberikan pemahaman secara mendalam, bahkan para mahasiswa menginap di rumah target-target tersebut, untuk memberikan keleluasaan waktu untuk berdialog, berdiskusi serta proses tanya jawab.

Kesadaran merupakan langkah awal yang penting bagi tumbuhnya gerakan sosial secara berkesinambungan. Kesadaran menjadi tahap awal bagaimana tahap-tahap dalam membangun gerakan sosial berjalan. Kesadaran kritis adalah target utama dalam proses pendidikan petani dari kesadaran petani yang pada awalnya terbagi ke dalam kesadaran magis, naif dan kritis. Masing-masing tingkatan 
kesadaran mendapat perlakuan yang berbeda dari para aktor dari sisi komunikasi dan jenis informasi yang disampaikan. Penyadaran terhadap petani yang tergolong dalam kesadaran magis adalah dengan menggunakan bahasa-bahasa yang sederhana dan mudah dipahami serta menggugah. Petani dalam kelompok kesadaran magis ini selain harus menggunakan pendekatan yang sedikit lama karena harus memunculkan rasa percaya terhadap kehadiran aktor gerakan, juga membutuhkan motivasi supaya mereka sadar akan keadaan yang mereka alami.

Perlakuan yang sedikit berbeda diberikan kepada petani yang tergolong dalam kelompok kesadaran naif. Pada dasarnya, petani kelompok kesadaran naif ini sudah tergugah untuk ikut dalam gerakan namun pada suatu kondisi mereka belum mempunyai prinsip yang kuat. Prinsip yang kuat seperti tidak mau berkompromi terhadap pihak perusahaan, menolak segala sesuatu yang ditawarkan pihak perusahaan dan menganggap bahwa mereka pada kondisi yang benar. Kesadaran naif ini terlihat ketika petani yang sudah terdorong untuk terlibat dalam gerakan namun ada yang menyerahkan lahannya karena perasaan takut dan tidak lagi yakin bahwa gerakan yang dilakukan akan berhasil. Komunikasi yang dilakukan oleh para aktor gerakan terhadap kelompok ini meliputi: (1) Melakukan komunikasi dengan intensitas yang lebih sering; (2) Memberikan pemahaman posisi petani dalam konflik seperti kekuatan hukum petani dalam konflik; (3) Memberikan motivasi untuk meyakinkan petani supaya teguh pada prinsip-prinsip perjuangan; (4) Memberikan pemahaman dasar terkait hukum agraria yang bersentuhan dengan konflik yang mereka alami.

Petani yang masuk dalam kelompok kesadaran kritis pada awal gerakan belum terlalu banyak. Kelompok ini teridentifikasi pada para tokoh tani lokal dan petani yang turut mendirikan Gabungan Petani Penggarap Pasirdatar Indah dan Sukamulya (GP3S). Petani dengan kesadaran kritis sudah mempunyai prinsip bahwa tanah yang mereka garap sebagai sumber ekonomi harus dipertahankan dan diperjuangkan. Komunikasi dialogis yang dilakukan oleh para aktor gerakan pun berbeda dengan dua jenis petani dengan kesadaran magis dan naif dalam gerakan ini. Komunikasi yang dilakukan meliputi: (1) Melakukan dialog dan diskusi terkait konflik agraria; (2) Memberikan pemahaman bagaimana menjalankan gerakan sosial secara mandiri; (3) Memberikan pemahaman terkait kebijakan dan produk hukum terkait konflik agraria.

Perbedaan perlakuan komunikasi dialogis oleh para aktor terhadap petani pada tingkatan kesadaran disampaikan oleh salah satu mahasiswa. Secara spesifik, para aktor tidak menyebutkan bentuk kesadaran magis, naif ataupun kritis. Aktor gerakan membagi petani pada tiga tingkatan atau grade yang secara tidak langsung mencirikan pada bentuk pembagian tingkat kesadaran. Grade pertama, adalah petani yang pada awalnya tidak mau terlibat sama sekali karena sudah pasrah akan keadaan, mereka menganggap lahan yang mereka garap akan menunggu waktu saja untuk diambil pihak perusahaan. Grade kedua adalah kelompok petani yang secara pemikiran mau untuk terlibat dan menganggap bahwa gerakan bisa menjadi solusi atas konflik yang mereka alami, namun petani grade ini masih belum bertindak sepenuh hati karena berbagai alasan dan tidak sepenuhnya ikut dalam aktivitas gerakan. Alasan yang digunakan biasanya karena takut, masih berharap ada kesepakatan damai dengan pihak perusahaan dan masih bersikap pesimis terhadap gerakan. Hal ini seperti ketika para aktor mengajaknya untuk ikut dalam berdemonstrasi, seperti yang diungkapkan salah satu petani:

\section{"Pada awalnya saya takut kalau ikut-ikut demo begitu, nanti saya ditangkap gak?, diapa-apain gak?" (DDE-Petani)}

Grade pertama dan kedua bisa dikelompokkan pada jenis kesadaran magis-naif karena pada dasarnya petani tidak sepenuhnya masuk pada grade satu. Petani tidak sepenuhnya pasrah pada keadaan tetapi juga mengharapkan sebuah perubahan yang terjadi namun rasa takut lebih mendominasi.

Grade ketiga adalah kelompok petani yang secara pemikiran sudah sadar bahwa mereka harus bergerak. Kelompok petani inilah yang menginisiasi gerakan pertama kali dengan membuat organisasi GP3S dengan salah satu gerakannya adalah menolak mengosongkan lahan. Kelompok petani ini juga yang meminta bantuan kepada mahasiswa untuk hadir dan memberikan informasi guna menguatkan organisasi gerakan mereka. Penjelasan ketiga grade ini diceritakan oleh salah satu aktor dari mahasiswa: 
"Pas kita datang pertama kali, kita sadar petani tidak semuanya sama, satu pemikiran. Ada yang gak mau ikut tadinya, ya akhirnya kita motivasi terus, kita datengin terus, di kebun, di rumah ya diajak ngobrol santai aja. Ada juga yang mau ikut gerakan cuman kadang takut, intinya sih masih belum percaya apa yang bakal kita lakuin akan berhasil. Kalau petani yang kita suka ya yang aktif-aktif, kalau diminta kumpul diskusi, rapat atau demo selalu siap, bahkan kayak demo mereka sampai patungan buat sewa mobil sama makannya". (YDR-Mahasiswa)

Saat ini kesadaran kritis petani terus dibangun selama proses gerakan sosial berlangsung. Dialog-dialog dengan petani terus dilakukan, dan posisi petani bukan menjadi objek dari gerakan sosial namun harus menjadi subjek dan aktor gerakan. Petani sudah mendapat peran-peran penting dalam proses terjadinya gerakan hingga saat ini. Petani juga sudah mulai mempunyai inisiatif atas langkah-langkah yang harus dilakukan ketika terjadi peristiwa tertentu walaupun tidak secara penuh. Salah satu aktor dari SPI menyadari bahwa sampai saat ini petani belum sepenuhnya paham dan masuk ke dalam kesadaran kritis $100 \%$, namun terjadi peningkatan dan kemajuan yang dialami petani tersebut, seperti yang diungkapkan oleh salah satu aktor dari SPI sebagai berikut:

"Ya kalau ukuran paham itu begini ya, indikatornya paham itu kan semua praktik sesuai dengan nilai, apa yang diajarkan, ideologi apa yang diajarkan oleh organisasi itu, sampai hari ini ya belum 100\%, karena terus proses ya, melalui pendidikan-pendidikan, pertemuan pertemuan, rapat-rapat, itu bagian dari mentransformasi, bagaimana nilai perjuangan itu diterapkan dalam keseharian perjuangan di organisasi, membicarakan isu-isu dan sebagainya. Kalau dari pertemuan ke pertemuan, ya itu bisa kita katakan ada kemajuan, sehingga kalau pertanyaannya paham dan ngerti, saya pikir ada kemajuan, ada perbedaan-perbedaan. Sekarang banyak pemuda-pemuda yang terlibat, yang dulunya tidak pernah dilibatkan dalam rapat-rapat, sekarang sudah dikasih peran-peran tertentu dan itu bagian dari kerja-kerja organisasi”. (ALI-SPI)

Bentuk kesadaran kritis salah satunya ditunjukkan dengan bagaimana petani memandang konflik, di mana mereka menyadari posisi mereka secara legalitas hukum dan berupaya memperjuangkannya dengan mencoba merubah sistem yang ada. Hal ini seperti yang diungkapkan salah satu petani:

"Sebagian keinginan masyarakat itu saya juga sama keinginannya, ingin punya tanah, sementara ini kan tanah pemerintah ya, tapi yang memegang HGB nya perusahaan. Tapi kan kalau perusahaan misalkan melanggar aturan, mungkin ada teguran, apalagi ini sudah lama" (DDN-Petani)

\section{Partisipasi Gerakan}

Komunikasi gerakan sosial menurut Habermas memerlukan tindakan komunikatif, mengacu pada tindakan yang diarahkan oleh norma-norma yang disepakati bersama berdasarkan harapan timbal balik diantara subjek-subjek yang berinteraksi dengan menggunakan simbol-simbol, khususnya bahasa sehari hari sebagai medium bagi tindakan tersebut (Setyowati, 2019). Komunikasi menjadi titik tolak dalam teori ini, dan praksis menjadi konsep sentralnya. Praksis bukan diartikan sebagai tingkah laku buta berdasarkan naluri belaka, melainkan tindakan dasar manusia sebagai makhluk sosial yang diterangi oleh kesadaran rasional. Tindakan komunikatif ini menjadi sebuah perwujudan bagaimana petani berpartisipasi dalam gerakan sosial yang terjadi setelah melalui proses penyadaran dan komunikasi dialogis.

Simpati petani dari awal konflik memang ada yang mendukung dan ada yang tidak bersimpati terhadap gerakan. Petani yang tidak bersimpati lebih banyak karena mendapat tekanan dan trauma akan konflik yang pernah dilaluinya. Petani yang bersimpati terhadap gerakan ini tidak langsung bersimpati, melainkan melalui proses yang panjang melalui proses penyadaran dan memberikan edukasi melalui advokasi dan setelah itu ada petani-petani yang aktif dan potensial untuk dijadikan sasaran mobilisasi. 
Petani-petani yang akhirnya berpartisipasi dalam gerakan adalah petani-petani yang kesadarannya sudah tumbuh serta paham akan realitas yang dihadapinya. Petani juga sudah mengerti bagaimana mereka memperjuangkan lahannya dan rela berkorban serta memandang gerakan ini adalah salah satu cara merebut keadilan agraria. Motivasi yang ada dalam diri petani bukan hanya menimbulkan semangat untuk ikut dalam gerakan, namun dengan suka rela berkorban materi dan non materi dalam setiap agenda gerakan. Pengorbanan materi seperti iuran ketika akan berdemonstrasi, ikut serta dalam menjamu setiap pertemuan, memfasilitasi para aktor yang sedang berada di lokasi dengan menjamu penginapan dan makan dan lain-lain. Pengorbanan non-materi adalah meluangkan waktu di saat harus menggarap lahan, di penjara ketika dilaporkan dan bergotong royong menggarap lahan petani yang sedang dalam masa tahanan.

Partisipasi petani dalam gerakan sosial ini cenderung mengalami perubahan seperti disajikan dalam Gambar 1 dan 2. Persentase perubahan partisipasi didapat dari kesaksian informan terhadap seluruh kepala keluarga yang lahannya masuk dalam arena konflik. Presentase perubahan pada Gambar 1 dinilai dari keaktifan petani pada fase awal gerakan pada tahun 2015-2016 saat masuknya aktor gerakan intelektual organik dan fase gerakan saat ini antara 2018-2019 saat penelitian ini dilaksanakan seperti tersaji pada gambar 2.

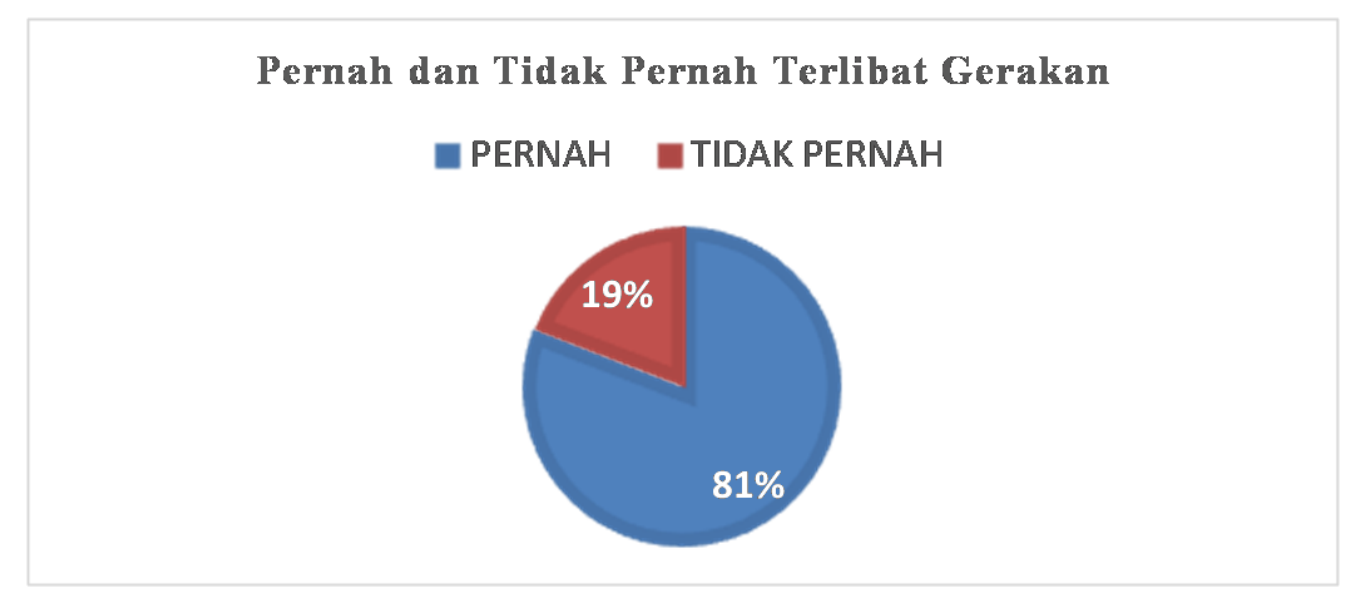

Gambar 1. Persentase petani yang pernah dan tidak pernah ikut dalam gerakan

Kesadaran petani yang digolongkan ke dalam kesadaran naif kritis terlihat dalam presentase partisipasi mereka dalam gerakan. Pada fase awal gerakan (dihitung saat masuknya aktor gerakan dan awal penyadaran dari 2015-2016) dari 486 kepala keluarga (KK) yang menggarap di lahan konflik, sebanyak $393 \mathrm{KK}$ atau $81 \%$ pernah terlibat dalam gerakan. Keterlibatan mereka di mulai dari keterlibatan aktif mereka dalam agenda rapat, diskusi, aksi demonstrasi, audiensi dan pengerahan massa. Sebanyak $93 \mathrm{KK}$ atau 19\% tidak terlibat sama sekali dalam gerakan karena beberapa hal, seperti sepakat dengan ketentuan perusahaan, akses lokasi yang sering tidak terjangkau proses advokasi dan memang merasa takut untuk terlibat.

Petani yang pada awalnya ikut dan terlibat dalam gerakan, mengalami penurunan partisipasi setelah beberapa insiden. Saat ini (saat dilaksanakan penelitian tahun 2018), petani yang masih bertahan dalam gerakan tersisa $203 \mathrm{KK}$ dengan sebanyak $190 \mathrm{KK}$ tidak lagi terlibat seperti yang tersaji pada Gambar 2. Insiden seperti penahanan beberapa tokoh petani atas laporan pihak perusahaan pada Oktober 2017 dan penahanan beberapa petani akibat pengrusakan kantor perusahaan pada Agustus 2017 yang banyak memengaruhi mental para petani. Paska insiden tersebut, bukan hanya angka partisipasi yang menurun namun jumlah petani yang menyerahkan lahannya semakin banyak. Seperti yang diungkapkan salah satu tokoh tani lokal:

"Sebanyak 82 petani di Pasir Datar udah, di Sukamulya 96 petani. Sisanya ya.. masih belum terdata, karena ada yang masih malu mengaku udah menyerahkan" (BBN-Petani) 


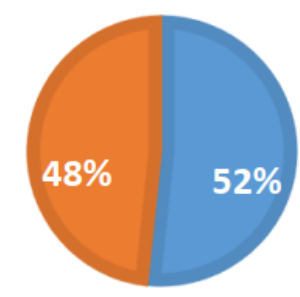

Gambar 2 Persentase petani yang bertahan dan tidak bertahan dalam gerakan tahun 2018

Partisipan seperti dalam penelitian ini menurut Hagopain (1978) terbagi dalam empat jenis. Pertama pemimpin dan aktivis, merupakan orang-orang yang secara penuh bersedia meluangkan waktu dan tenaga untuk mengarahkan organisasi dan aktivitas gerakan. Kedua transitory teams, dimaknai sebagai kumpulan beberapa individu yang berpartisipasi di dalam gerakan secara part time. Mereka pada dasarnya mengikuti seluruh aktivitas gerakan namun tidak seintens aktivis. Ketiga consience constituency, yaitu sekumpulan individu yang secara sukarela mengikuti aktivitas gerakan namun tidak terlalu terikat dengan aturan main gerakan. Kelompok ini memiliki peran penting yaitu menciptakan suasana yang menguntungkan bagi gerakan. Keempat sympathizer, merupakan orangorang yang berada di lingkaran paling luar gerakan. Meskipun mereka menyatakan dukungan terhadap gerakan namun tidak banyak aktivitas gerakan yang mereka ikuti (Kamajaya, 2010).

Tergolong pemimpin dan aktivis adalah pemimpin tani lokal yang terdiri dari ketua GP3S (BBN) dan mantan ketua GP3S (ASP), mahasiswa dan Serikat Petani Indonesia yang secara intens ikut terlibat serta menggerakan roda organisasi dalam mendukung gerakan secara konsisten. Kelompok kedua sampai keempat adalah golongan petani, meskipun terdampak konflik yang mengarah pada merugikan mereka dalam memenuhi skala ekonomi, petani masih terbagi ke dalam beberapa jenis partisipan ini. Petani ada yang masuk ke dalam jenis partisipan aktif dengan mengikuti segala jenis aksi kolektif dan aktif dalam menerima segala informasi yang berkaitan dengan gerakan bahkan ikut serta dalam pengkaderan SPI. Masuk ke dalam jenis ketiga, tipe petani ini akan turut ikut dalam gerakan tapi tidak ikut dalam proses penyadaran yang dilakukan oleh SPI karena memang tidak mau mengikuti aturan organisasi yang baku. Terakhir adalah kelompok petani yang hanya mendukung gerakan namun tidak ikut terlibat dalam gerakan. Petani yang tidak termotivasi sebenarnya merupakan sebuah fenomena yang biasa dihadapi oleh para aktor meskipun sudah berbagai upaya memengaruhi mereka seperti yang diungkapkan oleh aktor dari SPI berikut:

"Ya meskipun ada upaya kita memberikan kesadaran dengan berbagai cara tetap kita lakukan. Jadi dari sekian KK itu kan tidak semuanya (ikut berjuang). Itu sesuatu yang lumrah menurut saya, tinggal bagaimana kemudian tadi itu, biasanya begini, nanti kalau sudah hampir menang, sudah pasti hampir menang, orang akan berbondong-bondong, biasanya begitu”. (ALI-SPI)

\section{KESIMPULAN}

Gerakan sosial petani Caringin terbangun melalui proses penyadaran dengan menggunakan strategi komunikasi dialogis. Proses penyadaran tersebut dilakukan bersama aktor intelektual dari mahasiswa dan Serikat Petani Indonesia. Tingkat kesadaran petani yang didominasi oleh kesadaran magis mulai berubah kepada kesadaran naif-kritis. Kesadaran naif-kritis yang terjadi pada petani adalah pada satu sisi mereka sudah mulai sadar bahwa kondisi yang mereka alami karena suatu sistem yang salah dan sistematis, perlu ada perubahan yang harus mereka lakukan. Di sisi lain, kesadaran sebagian petani masih dibayangi ketakutan dan sifat pragmatis ketika ingin mendapatkan lahan dan penyelesaian secara instan. Kondisi ini diakibatkan karena pengalaman traumatis atas beberapa insiden penangkapan petani dan lemahnya posisi tawar petani dalam konflik dari sudut pandang hukum. Strategi penyadaran yang dilakukan oleh para aktor adalah dengan melakukan komunikasi dialogis bersama petani, komunikasi yang tidak menggurui dan menjabarkan realitas petani saat ini dengan posisi yang setara tanpa ada dominasi. 
Kasus-kasus yang menunjukkan adanya kesadaran naif yang masih melekat pada sebagian petani bisa menjadi sarana evaluasi bagi para aktor untuk lebih gencar dalam proses dialog. Kesadaran naif yang dicirikan oleh ketakutan dan ikut dalam aturan main perusahaan bahkan melibatkan tokoh tani lokal yang dianggap sudah masuk pada fase kesadaran kritis yang diakibatkan penahanan tokoh tersebut. Kasus ini harus menjadi perhatian bahwa pendampingan pasca insiden merupakan moment penting dan kritis karena ada kemungkinan menurunnya kesadaran akibat tekanan.

\section{DAFTAR PUSTAKA}

Amin, S. (2010). Mobilisasi dan Perubahan Sosial di Wilayah Konflik Agraria: Studi Kasus Paseduluran Petani Penggarap PT. Tratak (P4T). Jurnal Anlalisis Sosial, 15(1), 94-134.

Ansori. (2009). Rasionalitas Komunikatif Habermas. Komunika, 3(1), 90-100. http://download.portalgaruda.org/article.php?article $=49221 \&$ val=3911

Asia, N., Sarwoprasodjo, S., \& Gandasari, D. (2018). Dialog dan Tindakan Kolektif Kelompok Tani dalam Program Sertifikasi Kakao di Provinsi Sulawesi Barat. Jurnal Komunikasi Pembangunan, 16(1), 15-29. https://journal.ipb.ac.id/index.php/jurnalkmp/article/view/25118

Creswell, J. W. (2009). Research Design, Qualitative and Quantitative Approaches. SAGE Publications Inc.

Creswell, J. W. (2015). Penelitian Kualitatif dan Desain Riset, Memilih di antara Lima Pendekatan (S. Z. Qudsy (ed.)). Pustaka Pelajar.

Denzin, N. K., \& Lincoln, Y. S. (2009). Handbook of Qualitative Research (Saefudin Zuhri Qudsy (ed.); 2nd ed.). Pustaka Pelajar.

Eriyanto. (2011). Analisis Framing: Konstruksi, Ideologi dan Politik Media. LKiS.

Freire, P. (2008). Pendidikan Kaum Tertindas. LP3ES.

Hapsari, D. R. (2016). Peran Jaringan Komunikasi Dalam Gerakan Sosial Untuk Pelestarian Lingkungan Hidup. Jurnal Komunikasi Ikatan Sarjana Komunikasi Indonesia, 1(1), 25-36. https://doi.org/10.25008/jkiski.v1i1.33

Idrus, M. (2009). Metode Penelitian Ilmu Sosial Pendekatan Kualitatif dan Kuantitatif. Penerbit Erlangga.

Kamajaya, R. (2010). Transformasi Strategi Gerakan Petani. Research center for politics and goverment UGM.

Littlejohn, S. W., \& Foss, K. A. (2011). Teori Komunikasi (9th ed.). Salemba Humanika.

Moenawar, M. G., Priatna, W. B., \& Santoso, H. (2019). Consciousness Raising dan Partisipasi Politik Suku Baduy di Era Digital. Jurnal Komunikasi Pembangunan, 17(1), 69-80. https://doi.org/10.29244/jurnalkmp.17.1.69-80

Morissan. (2015). Teori Komunikasi, Individu Hingga Massa. Kencana.

Rachman, N. F. (2017). Petani dan Penguasa, Dinamika Perjalanan Politik Agraria Indonesia. Insist Press.

Roggeband, C., \& Klandermans, B. (2017). Handbook of social movements across disciplines (2nd ed.). Springer.

Setyadi, Y. (2016). Komunikasi Gerakan Sosial Penolakan Relokasi Kawasan Rawan Bencana Gunung Merapi (Kasus Desa Glagaharjo, Kecamatan Cangkringan, Kabupaten Sleman, DIY). IPB University.

Setyowati, Y. (2019). Komunikasi Pemberdayaan sebagai Perspektif Baru Pengembangan Pendidikan Komunikasi Pembangunan di Indonesia. Jurnal Komunikasi Pembangunan, 17(2), 188-199. https://journal.ipb.ac.id/index.php/jurnalkmp/article/view/26849/17221

Singh, R. (2010). Gerakan Sosial Baru. Resist Book.

Sugiyono. (2014). Memahami Penelitian Kualitatif. Alfa Beta. 
Susan, N. (2014). Pengantar Sosiologi Konflik. Kencana.

Syawaludin, M. (2014). Perlawanan Petani Rengas Terhadap PTPN VII di Ogan Ilir Sumatera Selatan. Jurnal Sosiologi Reflektif, 9(1), 113-130. http://ejournal.uinsuka.ac.id/isoshum/sosiologireflektif/article/view/1134/1045

Tauchid, M. (2009). Masalah Agraria Sebagai Masalah Penghidupan dan Kemakmuran Rakyat Indonesia. STPN Press.

Tufte, T., \& Mefalopulos, P. (2009). Participatory Communication, A Practical Guide. The World Bank.

Wijanarko. (2014). Komunikasi Penyadaran Kritis Gerakan Petani (Studi Kasus Gerakan Petani Serikat Paguyuban Petani Qaryah Thayyibah). IPB University.

Yin, R. K. (2015). Studi Kasus Desain dan Metode. Rajawali Press.

Yunus, F. M. (2007). Pendidikan Berbasis Realitas Sosial, Paulo Freire dan YB. Mangunwijaya. Logung Pustaka. 